\title{
Piroliza Py-GC-IRMS - elementy walidacji oznaczania on-line składu izotopowego węgla produktów pirolizy
}

\section{Pyrolysis Py-GC-IRMS - partial validation of on-line determination of carbon isotope composition}

\author{
Marek Janiga, Małgorzata Kania \\ Instytut Nafty i Gazu - Państwowy Instytut Badawczy
}

\begin{abstract}
STRESZCZENIE: Urządzenia pozwalające poddawać próbkę procesowi pirolizy w precyzyjnie określonych warunkach to pirolizery. Mogą one być łączone z różnymi aparatami, takimi jak chromatografy gazowe (z detektorami FID), spektrometry masowe oraz izotopowe spektrometry masowe. Zestawy GC-IRMS pozwalają na uzyskanie wartości $\delta^{13} \mathrm{C}$ poszczególnych związków z mieszaniny bez konieczności fizycznego jej rozdziału (rozdział następuje dzięki kolumnie chromatograficznej). Połączenie zestawu GC-IRMS z pirolizerem w układzie on-line pozwala na określanie składu izotopowego produktu pirolizy, a w zasadzie poszczególnych związków chemicznych produktu pirolizy. Praca przedstawia wyniki analiz produktów pirolizy próbki łupku sylurskiego. Otrzymywane produkty pirolizy to: metan, eten, etan, propylen, propan, 1-buten, n-butan oraz ditlenek węgla. Wykorzystana aparatura to spektrometr masowy Delta V Advantage firmy Thermo Scientific wraz z chromatografem Trace GC Ultra (kolumna kapilarna HP-PLOT Q, 30 m) i pirolizerem Pyroprobe 6150 (temperatura pirolizy $1000^{\circ} \mathrm{C}$, izoterma 30 sekund). Układ połączony on-line za pośrednictwem ConFlo IV. Metodyka Py-GC-IRMS oznaczeń składu izotopowego węgla gazowych produktów pirolizy została skalibrowana i sprawdzona poprzez ocenę powtarzalności i liniowości. Charakter oznaczeń składu izotopowego nie pozwala na określenie: granicy oznaczalności, granicy wykrywalności oraz obciążenia metody. Wszystkie wartości względnych odchyleń standardowych są poniżej pięciu procent (najniższe dla metanu: 0,6\%), co jest wynikiem zadowalającym i potwierdzającym, że metoda daje powtarzalne rezultaty. Na podstawie przeprowadzonych badań uznano, że liniowość nie powinna być oceniana dla tej metody, a brak spełnienia kryterium liniowości nie świadczy o gorszych wynikach.
\end{abstract}

Słowa kluczowe: piroliza, Py-GC-IRMS, walidacja, powtarzalność, liniowość.

\begin{abstract}
Devices allowing to perform a pyrolysis process under precisely defined conditions are pyrolyzers. They can be combined with various apparatus such as gas chromatographs (with FID detector), mass spectrometers and isotopic mass spectrometers. The GC-IRMS kits allow to obtain $\delta^{13} \mathrm{C}$ values of individual compounds from the mixture without the necessity of physical separation (the separation takes place in the chromatographic column). The combination of the on-line GC-IRMS kit with the pyrolyzer allows to determine the isotopic composition of the pyrolysis product (the individual chemical compounds of the pyrolysis product). The paper presents the results of analyses of the Silurian shale pyrolysis products. The pyrolysis products obtained are: methane, ethene, ethane, propylene, propane, 1-butene, n-butane and carbon dioxide. The apparatus used is a Thermo Scientific Delta V Advantage mass spectrometer with a Trace GC Ultra chromatograph (HP-PLOT/Q capillary column, $30 \mathrm{~m}$ ) and Pyroprobe 6150 pyrolyzer (pyrolysis temperature $1000^{\circ} \mathrm{C}$, isothermal 30 seconds). The Py-GC-IRMS methodology for determining the carbon isotopic composition of pyrolysis gas products has been calibrated and verified by evaluating repeatability and linearity. The nature of isotopic composition determinations does not allow to determine: the limit of quantification, the limit of detection and the method bias. All values of relative standard deviations are below five percent (the lowest for methane $0.6 \%$ ), which is satisfactory and confirms that the method is reproducible. Linearity should not be evaluated for this method, and the lack of fulfillment of the linearity criterion does not indicate worse results.
\end{abstract}

Key words: pyrolysis, PY-GC-IRMS, validation, repeatability, linearity.

\section{Wstęp}

Piroliza jest procesem termochemicznej dekompozycji w atmosferze beztlenowej. Jest to złożony proces rozpadu związków chemicznych do mniejszych molekuł pod wpływem dostarczonej z zewnątrz energii cieplnej. Parametry pirolizy (temperatura maksymalna, czas przebywania pierwotnych produktów rozkładu w strefie konwersji) wpływają na uzyskane produkty:

Autor do korespondencji: M. Janiga, e-mail: marek.janiga@inig.pl

Artykuł nadesłano do Redakcji 14.01.2019 r. Zatwierdzono do druku 17.04.2019 r. 
karbonizat, gaz pirolityczny lub frakcję ciekłą (Basu, 2010). Pirolizery pozwalają na analizę złożonych substancji, takich jak np.: guma z opon, tekstylia, farby, kleje, produkty petrochemiczne, archeologiczne artefakty, bakterie, polimery syntetyczne oraz produkty pochodzenia roślinnego (drewno, biomasa) (Almendros et al., 1999; Wampler, 1999; Simpson et al., 2005; Frade et al., 2009; Fabbri et al., 2010; González-Pérez et al., 2014). Pirolizery są wykorzystywane również w geochemii naftowej i łączone z różnymi typami aparatów (chromatografy, spektrometry masowe, izotopowe spektrometry masowe) (Kania i Janiga, 2015; Matyasik et al., 2017).

Metody i techniki oznaczania składu stabilnych izotopów były rozwijane od lat 30. ubiegłego wieku (Nier i Gulbransen, 1939; McKinney et al., 1950). Znaczące ulepszenie metodyki nastąpiło pod koniec lat 70. Wtedy udało się wprowadzić tzw. układ on-line, czyli połączyć izotopowy spektrometr z chromatografem gazowym (Sano et al., 1976; Matthews i Hayes, 1978; Sessions, 2006). Dzięki połączeniu izotopowych spektrometrów z chromatografami udało się wyeliminować czasochłonną i żmudną preparatykę próbek. Zestawy GC-IRMS pozwalają na uzyskanie wartości $\delta^{13} \mathrm{C}$ poszczególnych związków z mieszaniny bez konieczności fizycznego jej rozdziału (Freeman et al., 1990; Hayes et al., 1990; Abrajano et al., 1999). Kolejnym istotnym krokiem było poszerzenie tego układu o jednostkę pirolityczną i uzyskanie w ten sposób zestawu Py-GC-IRMS. Rozwój technik izotopowych był jednym z najbardziej znaczących kroków w geochemii naftowej (Philp, 2003).

Układy Py-GC-IRMS pozwalają na przeprowadzenie pirolizy asfaltenów. Skład izotopowy n-alkanów uzyskanych z pirolizy asfaltenów odpowiada składowi z niezdegradowanej ropy naftowej. Poznany skład izotopowy węgla poszczególnych n-alkanów może następnie być wykorzystany w celach korelacyjnych dla próbek niezdegradowanych oraz zdegradowanych. Dodatkowo możliwe jest wykonanie termodesorpcji związków, które normalnie byłyby ekstrahowane rozpuszczalnikami, lub termodesorpcji gazów (metan, etan i propan) z próbki skały (Mansuy et al., 1997; Philp, 2003).

Praca przedstawia wyniki analiz (dla celów walidacyjnych, oceny powtarzalności i liniowości) produktów pirolizy próbki łupku sylurskiego. Otrzymywane produkty pirolizy to: metan, eten, etan, propylen, propan, 1-buten, n-butan oraz ditlenek węgla.

\section{Metodyka}

Do oznaczeń składu izotopowego pierwiastków posiadających trwałe izotopy (węgiel, azot, tlen, wodór i siarka) wykorzystuje się spektrometry masowe (isotope ratio mass spectrometer, IRMS). Laboratorium Geochemii Nafty i Gazu INiG - PIB posiada spektrometr masowy Delta V Advantage firmy Thermo Scientific. Ze względu na wysoką czułość tego urządzenia oraz brak możliwości podawania bezwzględnego wyniku każde oznaczenie składa się z badania próbki oraz gazu referencyjnego, którego skład izotopowy jest określany przy użyciu certyfikowanych wzorców. Próbka musi trafić na spektrometr w postaci gazowej. Z tego względu ulega spaleniu w analizatorze elementarnym (Flash 2000) lub urządzeniu GC IsoLink połączonym z chromatografem Trace GC Ultra. Przepływy z analizatora, chromatografu oraz gazów referencyjnych zbierane są w ConFlo, urządzeniu pozwalającym ,zarządzać" strumieniami gazów trafiającymi do spektrometru. Dla oznaczeń składu izotopowego węgla próbka musi być w postaci ditlenku węgla, dla wodoru w postaci $\mathrm{H}_{2}$, dla tlenu w postaci $\mathrm{CO}$, a dla azotu w postaci $\mathrm{N}_{2}$. Te rodzaje gazów są referencyjne dla odpowiednich oznaczeń. Chromatograf na jednym z dozowników posiada dołączony pirolizer Pyroprobe 6150 (firmy CDS Analytical, rys. 2). Schemat układu Py-GC-IRMS został przedstawiony na rysunku 1.

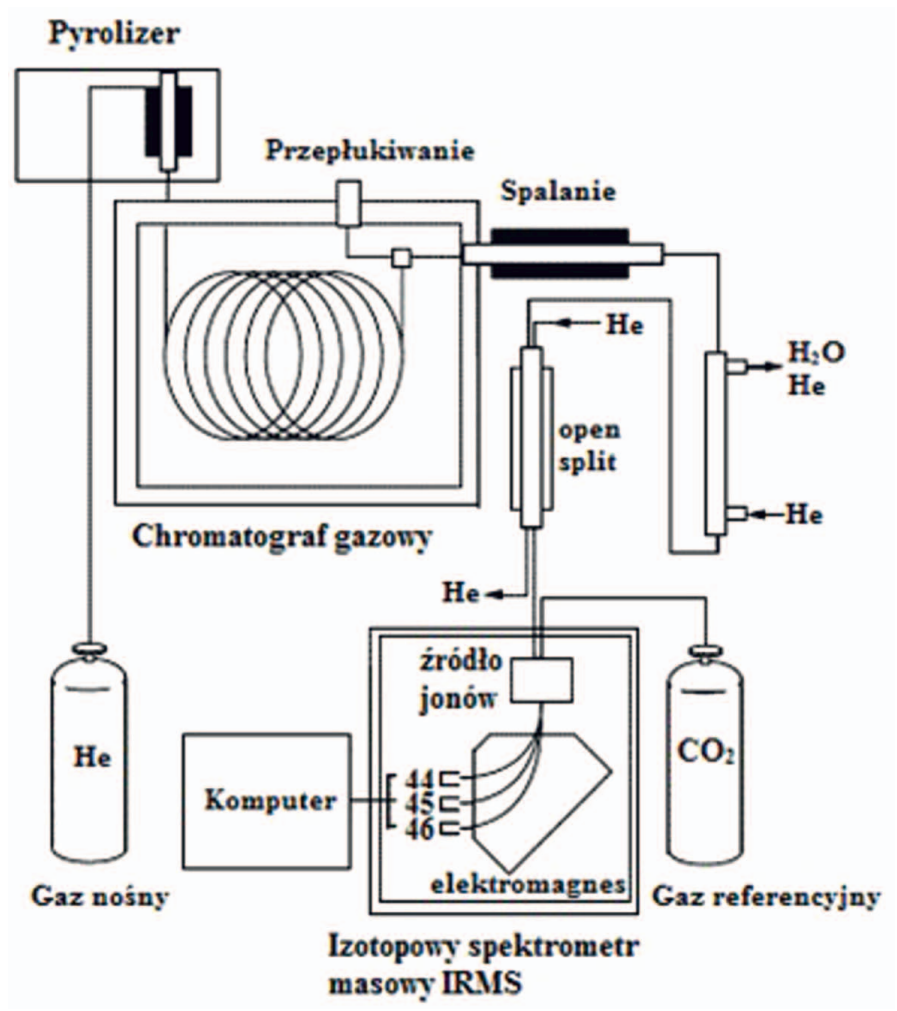

Rys. 1. Schemat układu Py-GC-IRMS (zmienione za Sephton i Gilmour, 2001)

Fig. 1. General schematic of Py-GC-IRMS (modified from Sephton and Gilmour, 2001)

Próbki gazów ulegają rozdziałowi na chromatografie Trace GC Ultra przy użyciu kolumny kapilarnej HP-PLOT Q o długości 30 metrów i średnicy 0,32 mm. Program temperaturowy rozpoczyna się $\mathrm{w} 25^{\circ} \mathrm{C}$ (izoterma utrzymywana przez 4 minuty). 
Następnie następuje wzrost temperatury do $210^{\circ} \mathrm{C}$ (izoterma utrzymywana przez 5 minut). Temperatura dozownika wynosi $150^{\circ} \mathrm{C}$. Kolejne rozdzielone składniki gazu opuszczające kolumnę są spalane do $\mathrm{CO}_{2}$ i $\mathrm{H}_{2} \mathrm{O}$ w reaktorach urządzenia $\mathrm{GC}$ IsoLink (wypełnienie $\mathrm{CuO}$, temperatura $1000^{\circ} \mathrm{C}$ ). W celu wyeliminowania wilgoci produkty spalania wraz z gazem nośnym przepływają przez rurkę nafionową. Następnie trafiają do ConFlo IV (open split) i na IRMS (Delta V Advantage). Do wykonania kalibracji użyto wzorca Alphagas isotope $-\mathrm{CO}_{2}$. Certyfikowany wzorzec gazowy został zakupiony w firmie AirLiquide Polska. Wzorzec został sporządzony w akredytowanym laboratorium Air Liquide Deutschland GmbH w Düsseldorfie. Kalibracja została wykonana poprzez sześciokrotną analizę wzorca Alphagas isotope $-\mathrm{CO}_{2} \mathrm{o}$ wartości $\delta^{13} \mathrm{C}$ wynoszącej $-36,20 \%$ (PDB) i odchyleniu standardowym $0,2 \%$.

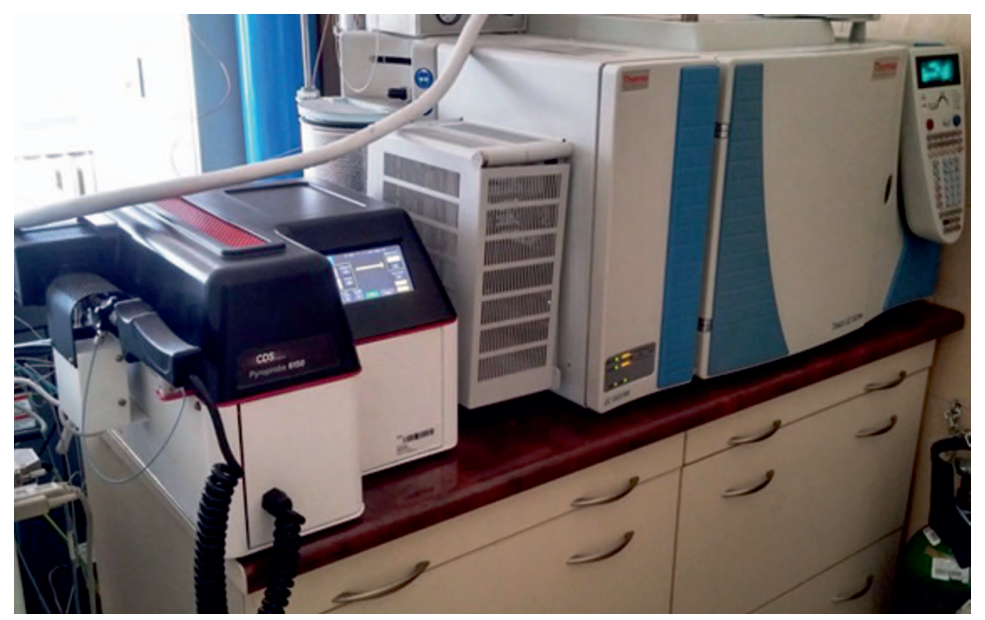

Rys. 2. Pirolizer Pyroprobe 6150 połączony z chromatografem gazowym Trace GC Ultra

Fig. 2. Pyrolyzer Pyroprobe 6150 connected with gas chromatograph Trace GC Ultra

Pirolizer Pyroprobe 6150 składa się z dwóch głównych części: „,sondy”, w której umieszcza się próbkę, oraz interface’u (dalej: interfejs), w którym umieszcza się sondę. Dodatkowo mogą być ustawiane parametry pracy dwóch stref: linii transferowej oraz komory zaworu ośmiodrożnego (umożliwiającego przepływ gazu nośnego w dwóch liniach).

Próbka umieszczana jest w szklanej (kwarcowej) rurce, następnie w tzw. sondzie, w której znajduje się platynowy żarnik - filament. Jest to element grzejny w kształcie sprężyny, wewnątrz którego znajduje się rurka z próbką. Temperatura oraz czas jej odziaływania to najważniejsze parametry pracy pirolizera. Zalecana przez producenta metoda SS-13 przeznaczona dla próbek geologicznych wykorzystuje temperaturę pirolizy $1000^{\circ} \mathrm{C}$ przez 30 sekund. Przyrost temperatury to $20^{\circ} \mathrm{C}$ na milisekundę. Sonda umieszczana jest $\mathrm{w}$ interfejsie, którego temperaturę (początkową, końcową, narost) również można zaprogramować. Temperatura początkowa to $50^{\circ} \mathrm{C}$, przyrost $100^{\circ} \mathrm{C} / \mathrm{min}$, a temperatura końcowa to $400^{\circ} \mathrm{C}$ (utrzymywane przez trzy minuty). Temperatury linii transferowej łączącej pirolizer z dozownikiem chromatografu oraz komory z zaworem są ustawione odpowiednio na $350^{\circ} \mathrm{C}$ i $325^{\circ} \mathrm{C}$.

\section{Elementy walidacji}

Walidacja to proces ustalania parametrów charakteryzujących sprawność działania metody, określania jej ograniczeń oraz sprawdzania jej przydatności do określonych celów. W efekcie wykonania walidacji można uzyskać pewność, że proces analizy przebiega w sposób rzetelny i precyzyjny oraz daje wiarygodne wyniki. Parametry metody, które powinny być wyznaczone podczas walidacji lub określania niepewności pomiaru, to: powtarzalność wyników metody badawczej, liniowość i odtwarzalność metody badawczej, dokładność pomiaru, granica oznaczalności, granica wykrywalności i obciążenia metody.

Metodyka Py-GC-IRMS oznaczeń składu izotopowego węgla gazowych produktów pirolizy została sprawdzona poprzez ocenę powtarzalności i liniowości. Kryteria akceptacji to, odpowiednio, względne odchylenie standardowe RSD wyrażone w procentach poniżej $5 \%$ oraz współczynnik korelacji $R$ powyżej 0,999 lub $R^{2}$ powyżej 0,998 (Michalski i Mytych, 2008).

Dokładność metody (zgodność pomiędzy wartością rzeczywistą a wartością będącą wynikiem analizy) nie mogła być sprawdzona ze względu na brak certyfikowanych materiałów odniesienia innych niż gaz użyty do kalibracji. Mieszany charakter oznaczeń składu izotopowego (ilościowo-jakościowy) nie pozwala na określenie: granicy oznaczalności (najmniejsza ilość substancji, jaka może być wiarygodnie oznaczona), granicy wykrywalności (najmniejsza ilość substancji, jaka może być wykryta) oraz obciążenia metody (,,różnica” pomiędzy wynikiem uzyskanym metodą badaną i wynikiem badania tej samej próbki metodą odniesienia). Ilość próbki musi być tak dobrana, aby piki poszczególnych związków mieściły się w zakresie roboczym detektora (kolektorów Faradaya). Metoda odniesienia, która mogłaby zostać wykorzystana, nie istnieje.

\section{Powtarzalność}

Badanie powtarzalności zostało wykonane poprzez sześciokrotną analizę próbki łupku K-1. Wyniki kolejnych oznaczeń przedstawiono w tabeli 1. Wartości najmniejsze, wartości największe, rozstęp, średnie arytmetyczne, odchylenia standardowe oraz względne odchylenia standardowe dla poszczególnych 
Tabela 1. Skład izotopowy węgla w produktach pirolizy - powtarzalność

Table 1. Carbon isotope composition of pyrolysis products - repeatability

\begin{tabular}{|l|c|c|c|c|c|c|}
\cline { 2 - 7 } & \multicolumn{7}{|c|}{ I (6450) } & II (6465) & III (6466) & IV (6470) & V (6479) & VI (6478) \\
\cline { 2 - 7 } & \multicolumn{7}{|c|}{$[\%]$} \\
\hline \hline $\mathrm{CO}_{2}$ & $-7,79$ & $-7,75$ & $-7,60$ & $-7,56$ & $-7,73$ & $-7,55$ \\
\hline Metan & $-31,27$ & $-31,07$ & $-30,91$ & $-31,27$ & $-31,31$ & $-31,36$ \\
\hline Eten & $-29,19$ & $-28,57$ & $-28,55$ & $-28,95$ & $-29,57$ & $-29,40$ \\
\hline Etan & $-27,20$ & $-28,03$ & $-28,36$ & $-27,98$ & $-29,60$ & $-28,08$ \\
\hline Propylen & $-25,75$ & $-25,58$ & $-25,80$ & $-25,88$ & $-27,52$ & $-26,30$ \\
\hline Propan & $-24,01$ & $-25,32$ & $-25,84$ & $-24,91$ & $-26,54$ & $-24,15$ \\
\hline 1-Buten & $-24,47$ & $-24,01$ & $-24,40$ & $-24,94$ & $-25,88$ & $-24,87$ \\
\hline n-Butan & $-23,40$ & $-23,34$ & $-24,63$ & $-23,55$ & $-25,51$ & $-22,66$ \\
\hline
\end{tabular}

Tabela 2. Parametry statystyczne - powtarzalność

Table 2. Statistical parameters - repeatability

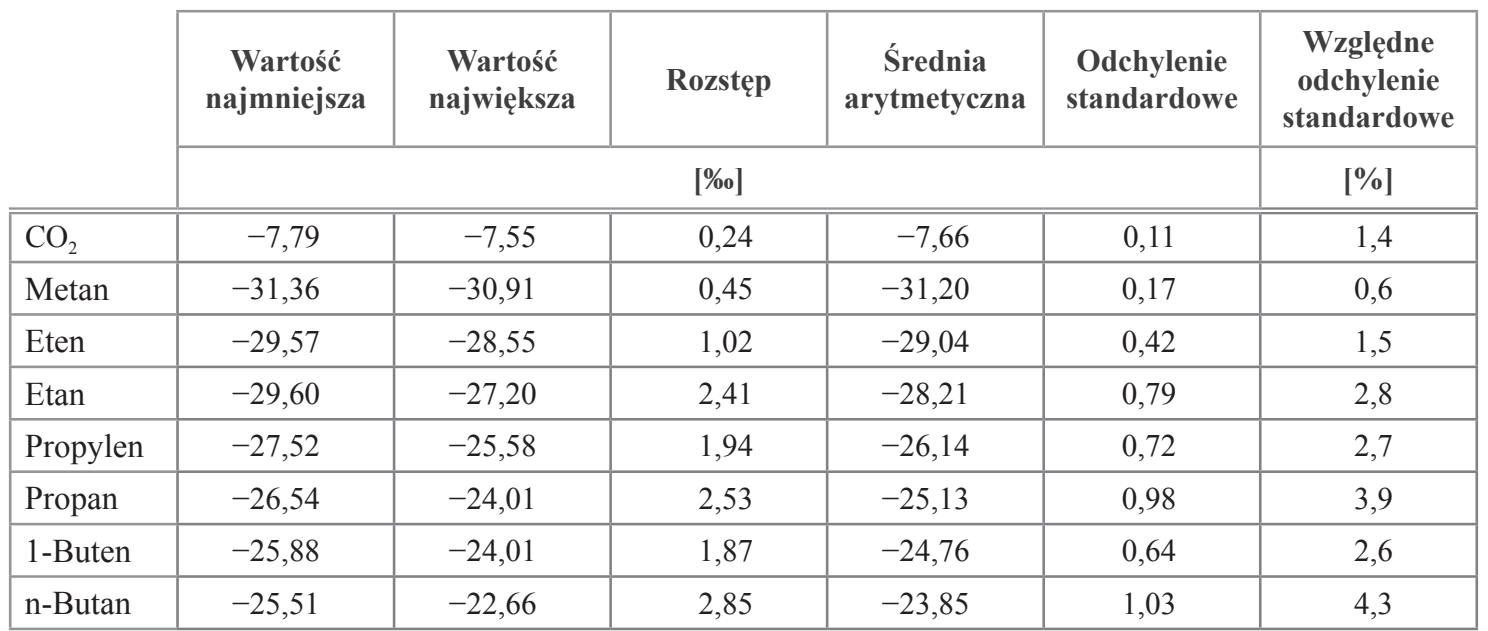

związków zostały przedstawione w tabeli 2 . Parametry statystyczne wskazują, że najbardziej powtarzalne są oznaczenia $\delta^{13} \mathrm{C}$ dla metanu i ditlenku węgla, w przypadku pozostałych węglowodorów bardziej powtarzalne są oznaczenia dla nienasyconych niż dla odpowiednich węglowodorów nasyconych.

Najniższe odchylenie standardowe wynosiło $0,11 \%$ dla ditlenku węgla, a najwyższe $1,03 \%$ dla n-butanu. Najniższe względne odchylenia standardowe to $0,6 \%$ dla metanu. Wszystkie wartości względnych odchyleń standardowych są poniżej pięciu procent, co jest wynikiem zadowalającym i potwierdzającym, że metoda jest powtarzalna (Michalski i Mytych, 2008).

\section{Liniowość}

Ocena liniowości metody została wykonana poprzez pojedyncze analizy próbki łupku K-1 na sześciu poziomach (sześć różnych naważek próbki). Wyniki analiz składu izotopowego węgla oraz pola powierzchni pików (wyrażone jako sekunda razy wolt $-\mathrm{sV}$ ) zostały zebrane $\mathrm{w}$ tabeli 3 , a parametry statystyczne w tabeli 4 . Wykresy zestawiające $\delta^{13} \mathrm{C}$ i pole powierzchni piku dla poszczególnych produktów pirolizy wraz z liniami trendu (regresja liniowa) i współczynnikami dopasowania $R^{2}$ zostały przedstawione na rysunkach od 3 do 6 . Wszystkie współczynniki dopasowania przyjmują niskie wartości i metoda nie jest liniowa. Jednakże odchylenie standardowe i względne odchylenie standardowe przyjmują niższe wartości niż w ocenie powtarzalności dla sześciu składników. Tylko dla dwóch są wyższe, przy czym dla jednego (etenu) bardzo nieznacznie. Jedynie ditlenek węgla charakteryzuje się wysokimi wartościami odchylenia standardowego i względnego odchylenia standardowego (wartość 7,4\%, która nie może być zaakceptowana przy ocenie powtarzalności). To oznacza, że dla sześciu składników, mimo braku liniowości, wyniki są lepsze niż w ocenie powtarzalności. Może to być związane ze specyfiką badań składu izotopowego w spektrometrach typu IRMS, gdzie oznaczenie nie ma charakteru ilościowego. Biorąc to pod uwagę, wydaje się, że liniowość nie powinna być oceniana dla tej metody, a brak spełnienia kryterium liniowości nie świadczy o gorszych wynikach. 
Tabela 3. Skład izotopowy węgla w produktach pirolizy - liniowość

Table 3. Carbon isotope composition of pyrolysis products - linearity

\begin{tabular}{|c|c|c|c|c|c|c|c|c|c|c|c|c|}
\hline & \multicolumn{2}{|c|}{ 1. poziom (6456) } & \multicolumn{2}{|c|}{ 2. poziom (6457) } & \multicolumn{2}{|c|}{ 3. poziom (6463) } & \multicolumn{2}{|c|}{ 4. poziom (6464) } & \multicolumn{2}{|c|}{ 5. poziom (6465) } & \multicolumn{2}{|c|}{ 6. poziom (6455) } \\
\hline & 泀 & 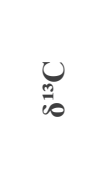 & 泀 & $\underset{\frac{m}{\infty}}{U}$ & 气 & $\bigcup_{\frac{m}{10}}$ & 泀 & $\begin{array}{l}\frac{U}{m} \\
\frac{m}{10}\end{array}$ & 泀 & $\begin{array}{l}\underbrace{}_{0} \\
\frac{m}{10}\end{array}$ & 泀 & $\underset{m}{\cup}$ \\
\hline & \multicolumn{12}{|c|}{ [sV, \%o] } \\
\hline $\mathrm{CO}_{2}$ & 45,42 & $-8,60$ & 55,09 & $-8,43$ & 78,72 & $-8,96$ & 119,12 & $-8,68$ & 161,62 & $-7,75$ & 168,51 & $-7,34$ \\
\hline Metan & 31,16 & $-31,23$ & 38,10 & $-31,16$ & 53,63 & $-31,01$ & 81,94 & $-31,09$ & 112,06 & $-31,07$ & 119,67 & $-30,96$ \\
\hline Eten & 15,90 & $-28,25$ & 13,10 & $-29,01$ & 21,84 & $-29,07$ & 48,34 & $-28,42$ & 63,51 & $-28,57$ & 45,91 & $-29,52$ \\
\hline Etan & 3,87 & $-28,59$ & 5,11 & $-28,95$ & 6,72 & $-29,05$ & 9,26 & $-28,53$ & 11,37 & $-28,03$ & 11,93 & $-28,34$ \\
\hline Propylen & 8,84 & $-26,10$ & 9,12 & $-27,03$ & 13,46 & $-26,71$ & 25,85 & $-25,88$ & 32,08 & $-25,58$ & 26,55 & $-26,14$ \\
\hline Propan & 0,98 & $-26,95$ & 1,33 & $-26,17$ & 2,04 & $-26,86$ & 2,46 & $-25,65$ & 2,83 & $-25,32$ & 2,43 & $-24,41$ \\
\hline 1-Buten & 4,25 & $-24,54$ & 4,03 & $-25,47$ & 5,94 & $-25,19$ & 12,98 & $-24,33$ & 16,70 & $-24,01$ & 13,46 & $-24,49$ \\
\hline n-Butan & 0,88 & $-24,70$ & 1,16 & $-25,75$ & 1,49 & $-25,26$ & 1,71 & $-23,76$ & 2,01 & $-23,34$ & 1,81 & $-24,27$ \\
\hline
\end{tabular}

Tabela 4. Parametry statystyczne - liniowość

Table 4. Statistical parameters - linearity

\begin{tabular}{|c|c|c|c|c|c|c|c|}
\hline & $\begin{array}{c}\text { Wartość } \\
\text { najmniejsza }\end{array}$ & $\begin{array}{c}\text { Wartość } \\
\text { największa }\end{array}$ & Rozstęp & $\begin{array}{c}\text { Średnia } \\
\text { arytmetyczna }\end{array}$ & $\begin{array}{c}\text { Odchylenie } \\
\text { standardowe }\end{array}$ & \multirow{2}{*}{$\begin{array}{c}\text { Względne odchylenie } \\
\text { standardowe }\end{array}$} & \multirow[t]{2}{*}{$R^{2}$} \\
\hline & \multicolumn{5}{|c|}{ [\%o] } & & \\
\hline $\mathrm{CO}_{2}$ & $-8,96$ & $-7,34$ & 1,62 & $-8,29$ & 0,62 & 7,4 & 0,61 \\
\hline Metan & $-31,23$ & $-30,96$ & 0,27 & $-31,09$ & 0,10 & 0,3 & 0,54 \\
\hline Eten & $-29,52$ & $-28,25$ & 1,28 & $-28,81$ & 0,48 & 1,7 & 0,00 \\
\hline Etan & $-29,05$ & $-28,03$ & 1,02 & $-28,58$ & 0,38 & 1,3 & 0,52 \\
\hline Propylen & $-27,03$ & $-25,58$ & 1,46 & $-26,24$ & 0,54 & 2,0 & 0,60 \\
\hline Propan & $-26,95$ & $-24,41$ & 2,54 & $-25,89$ & 0,97 & 3,8 & 0,50 \\
\hline 1-Buten & $-25,47$ & $-24,01$ & 1,46 & $-24,67$ & 0,55 & 2,2 & 0,65 \\
\hline n-Butan & $-25,75$ & $-23,34$ & 2,42 & $-24,51$ & 0,91 & 3,7 & 0,51 \\
\hline
\end{tabular}
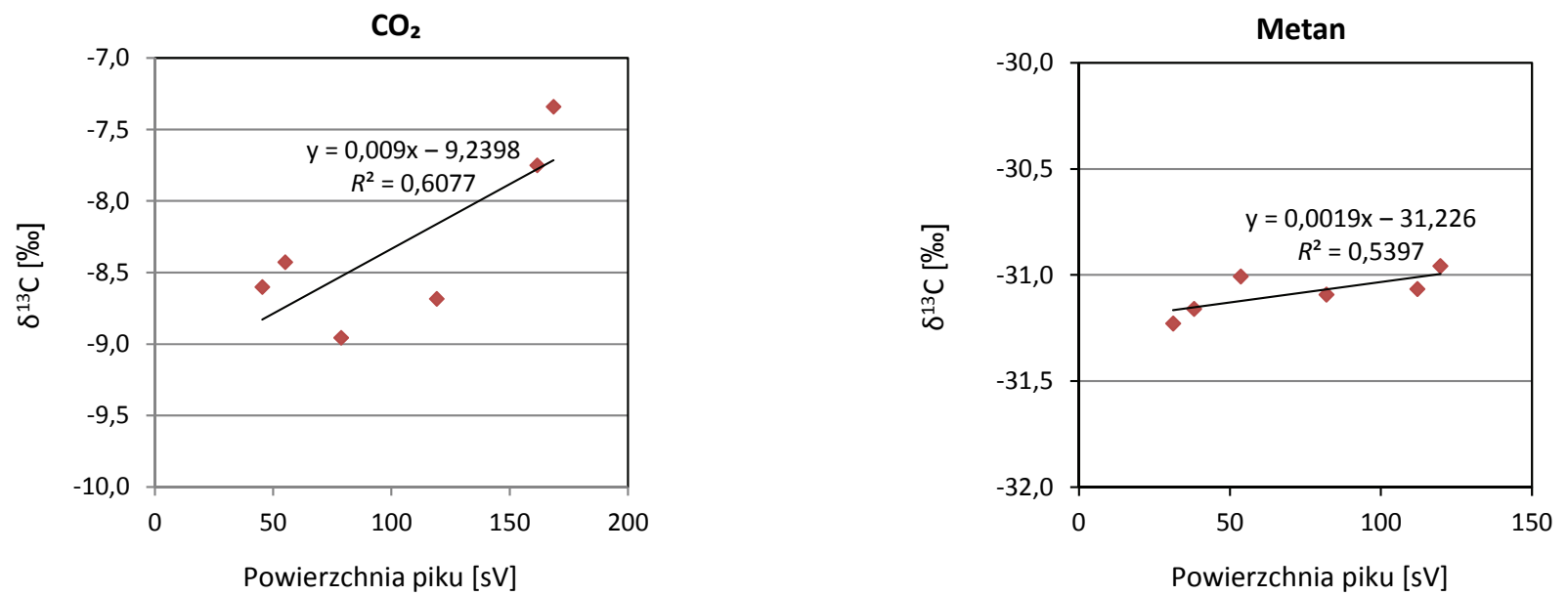

Rys. 3. Wykresy zestawiające $\delta^{13} \mathrm{C}$ i pole powierzchni piku dla ditlenku węgla i metanu [\%o, sV]

Fig. 3. Diagram comparing $\delta^{13} \mathrm{C}$ and peak area for carbon dioxide and methane [\%o, $\left.\mathrm{sV}\right]$ 


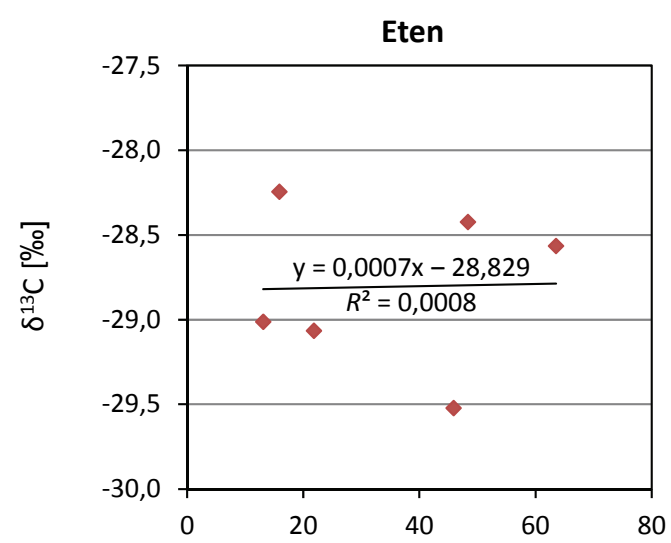

Powierzchnia piku [sV]

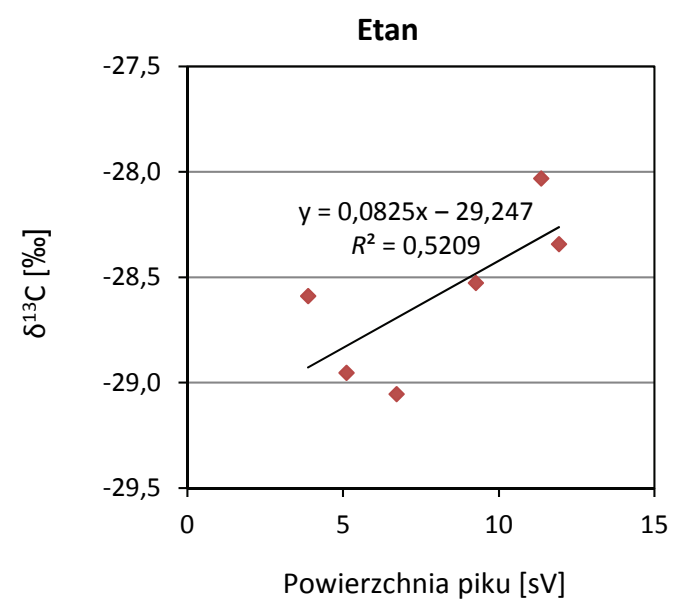

Powierzchnia piku [sV]

Rys. 4. Wykresy zestawiające $\delta^{13} \mathrm{C}$ i pole powierzchni piku dla etenu i etanu [\%o, sV]

Fig. 4. Diagram comparing $\delta^{13} \mathrm{C}$ and peak area for ethane and ethane [\%o, sV]
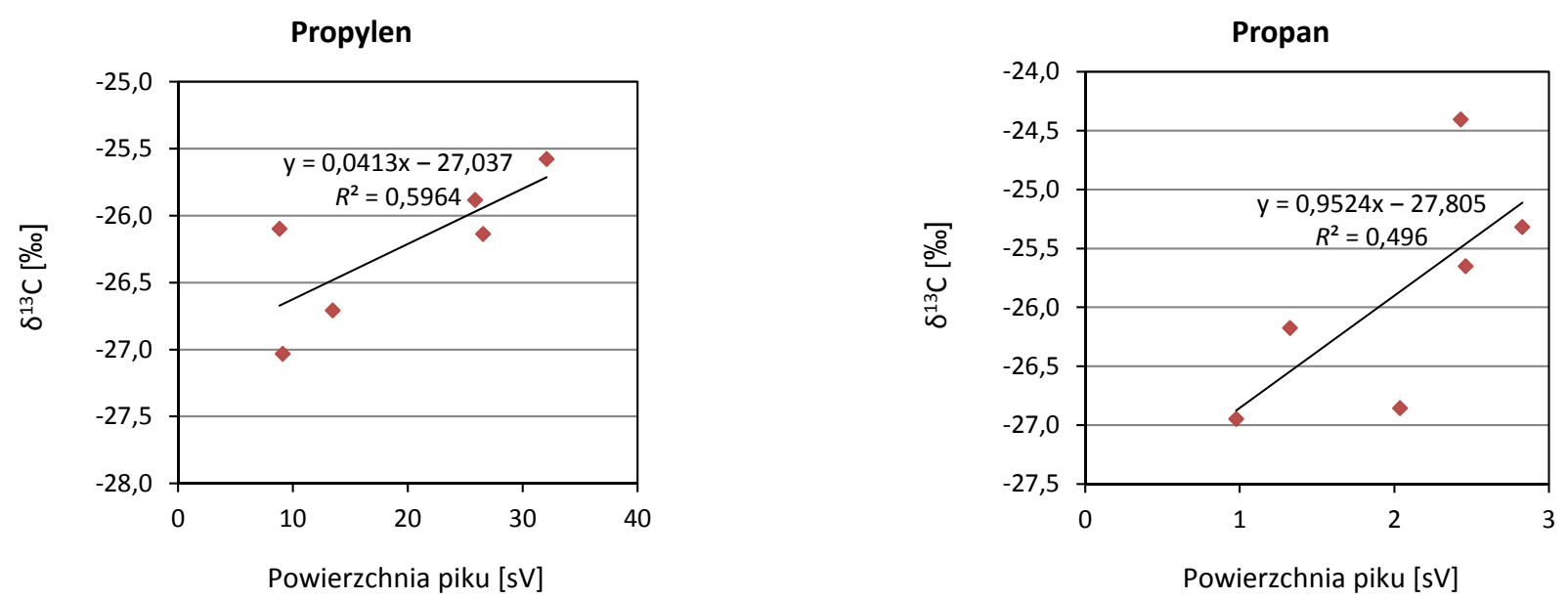

Rys. 5. Wykresy zestawiające $\delta^{13} \mathrm{C}$ i pole powierzchni piku dla propylenu i propanu [\%o, sV]

Fig. 5. Diagram comparing $\delta^{13} \mathrm{C}$ and peak area for propylene and propane [\%o, sV]

1-Buten

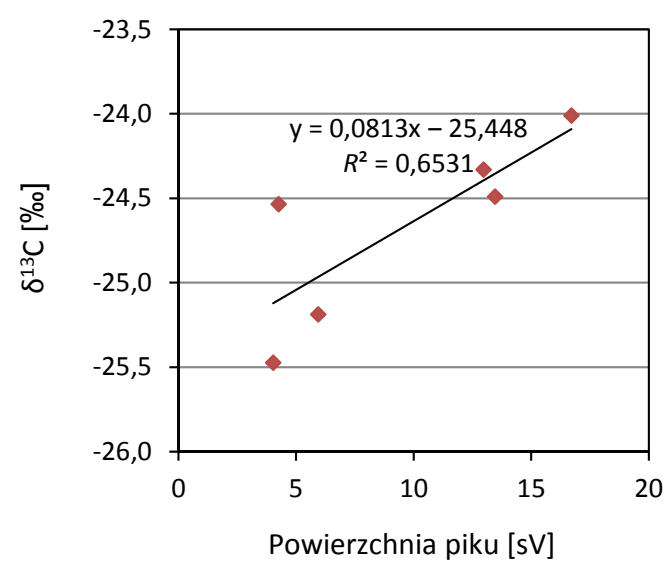

n-Butan

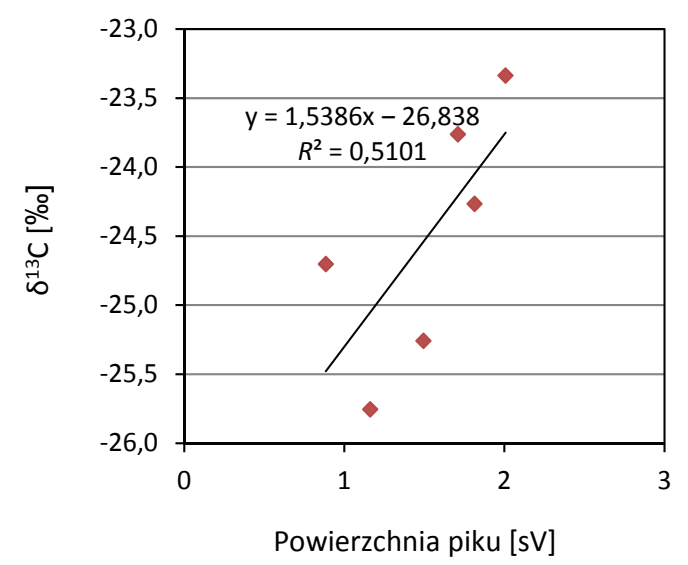

Rys. 6. Wykresy zestawiające $\delta^{13} \mathrm{C}$ i pole powierzchni piku dla 1-butenu i n-butanu [\%o, sV]

Fig. 6. Diagram comparing $\delta^{13} \mathrm{C}$ and peak area for 1-buthene and n-buthane [\%o, sV] 


\section{Podsumowanie}

Powtarzalność wyników została oceniona poprzez sześciokrotną analizę próbki łupku K-1. Wszystkie wartości względnych odchyleń standardowych są poniżej pięciu procent (najniższe dla metanu: $0,6 \%$ ), co jest wynikiem zadowalającym i potwierdzającym, że metoda daje powtarzalne wyniki.

Liniowość została oceniona poprzez analizę próbki na sześciu poziomach (łupek K-1). Liniowość nie powinna być oceniana dla tej metody, a brak spełnienia kryterium liniowości nie świadczy o gorszych wynikach, ponieważ odchylenie standardowe i względne odchylenie standardowe przyjmują niższe wartości niż w ocenie powtarzalności dla sześciu składników. Tylko dla dwóch są wyższe, przy czym dla jednego (etenu) - bardzo nieznacznie.

Artykuł powstał na podstawie pracy statutowej pt.: Piroliza PY-GC-IRMS-oznaczanie ,on-line” sktadu izotopowego węgla produktów pirolizy/termodesorbcji-praca INiG - PIB na zlecenie MNiSW; nr zlecenia: 45/SG/18, nr archiwalny: DK- 4100-45/18.

\section{Literatura}

Abrajano J., Lollar B.S., 1999. Compound-specific isotope analysis: tracing organic contaminant sources and processes in geochemical systems. Organic Geochemistry, 30(8/1): v-vii.

Almendros G., Dorado J., González-Vila F.J., Martín F., Sanz J., Álvarez-Ramis C., Stuchlik L., 1999. Molecular characterization of fossil organic matter in Glyptostrobus europaeus remains from the Orawa basin (Poland): comparison of pyrolytic techniques. Fuel, 78: 745-752.

Basu P., 2010. Biomass gasification and pyrolysis. Practical design and theory. Academic Press. ISBN 9780123749888.

Fabbri D., Adamiano A., Torri C., 2010. GC-MS determination of polycyclic aromatic hydrocarbons evolved from pyrolysis of biomass. Anal. Bioanal. Chem., 397: 309-317.

Frade J.C., Ribeiro M.I., Graça J., Rodrigues J., 2009. Applying pyrolysis-gas chromatography/mass spectrometry to the identification of oriental lacquers: study of two lacquered shields. Anal. Bioanal. Chem., 395: 2167-2174.

Freeman K.H., Hayes J.M., Trendel J.M., Albrecht P., 1990. Evidence from carbon isotope measurements for diverse origins of sedimentary hydrocarbons. Nature, 343: 254-256.

González-Pérez J.A., Almendros G., de la Rosa J.M., González-Vila F.J., 2014. Appraisal of polycyclic aromatic hydrocarbons (PAHs) in environmental matrices by analytical pyrolysis (Py-GC/MS).

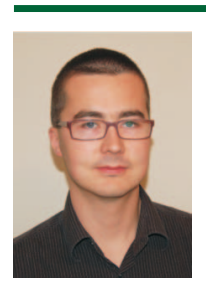

Mgr inż. Marek JANIGA

Asystent w Zakładzie Geologii i Geochemii

Instytut Nafty i Gazu - Państwowy Instytut Badawczy

ul. Lubicz $25 \mathrm{~A}$

31-503 Kraków

E-mail: marek.janiga@inig.pl
Journal of Analytical and Applied Pyrolysis, 109: 1-8. DOI: 10.1016/j.jaap.2014.07.005.

Hayes J.M., Freeman K.H., Popp B.N., Hoham C.H., 1990. Compound specific isotope analysis: a novel tool for reconstruction of ancient biogeochemical processes. Organic Geochemistry, 16: 1115-1128.

Kania M., Janiga M., 2015. Wykorzystanie pirolitycznej chromatografii gazowej do określania składu produktów symulowanego procesu generowania węglowodorów. Nafta-Gaz, 10: 720-728. DOI: $10.18668 / \mathrm{NG} 2015.10 .02$.

Mansuy L., Philp R.P., Allen J.D., 1997. Source identification of oil spills based on the isotopic composition of individual components in weathered oil samples. Environmental Science \& Technology, 31: 3417-3425.

Matthews D.E., Hayes J.M., 1978. Isotope-ratio-monitoring gas chromatography-mass spectrometry. Analytical Chemistry, 50: 1465-1473.

Matyasik I., Kierat M., Kania M., Brzuszek P., 2017. Ocena jakościowa węglowodorów generowanych z różnego typu skał macierzystych oparta na wynikach badań PY-GC, Rock-Eval i Leco. Nafta-Gaz, 10: 719-729. DOI: 10.18668/NG.2017.10.01.

McKinney C.R., McCrea J.M., Epstein S., Allen H.A., Urey H.C., 1950. Improvements in mass spectrometers for the measurement of small differences in isotope abundance ratios. Review of Scientific Instruments, 21: 724-730.

Michalski R., Mytych J., 2008. Akredytacja laboratoriów badawczych według normy PN-EN ISO/IEC 17025. Katowice: Wydawnictwo Elamed. ISBN 978-83-61190-00-4.

Nier A.O., Gulbransen E.A., 1939. Variations in the Relative Abundance of the Carbon Isotopes. Journal of the American Chemical Society, 61: 697-698.

Philp R.P., 2003. The Use of Thermal Analytical Methods in Organic Geochemistry. W: Ikan R. (ed.), Natural and Laboratory Simulated Thermal Geochemical Processes (s. 297-323). Dordrecht: Springer.

Sano M., Yotsui Y., Abe H., Sasaki S., 1976. A new technique for the detection of metabolites labelled by the isotope 13C using mass fragmentography. Biomedical Mass Spectrometry, 3: 1-3.

Sephton M.A., Gilmour I., 2001. Pyrolysis-gas chromatographyisotope ratio mass spectrometry of macromolecular material in meteorites. Planetary and Space Science, 49(5): 465-471.

Sessions A.L., 2006. Isotope-ratio detection for gas chromatography. Journal of Separation Science, 29: 1946-1961.

Simpson M.J., Chefetz B., Deshmukh A.P., Hatcher P.G., 2005. Comparison of polycyclic aromatic hydrocarbon distributions and sedimentary organic matter characteristics in contaminated, coastal sediments from Pensacola Bay, Florida. Mar. Environ. Res., 59(2): 139-163.

Wampler T.P., 1999. Introduction to pyrolysis-capillary gas chromatography. J. Chromatogr. A, 842: 207-220.

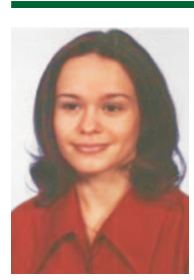

Mgr Małgorzata KANIA

Asystent w Zakładzie Geologii i Geochemii Instytut Nafty i Gazu - Państwowy Instytut Badawczy ul. Lubicz 25 A

31-503 Kraków

E-mail: malgorzata.kania@inig.pl 